\title{
What caused extreme ozone concentrations over Cotonou in December 2005?
}

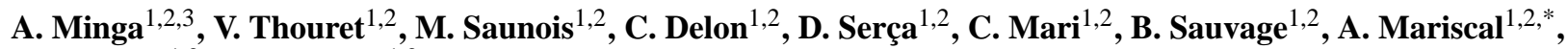 \\ M. Leriche ${ }^{1,2}$, and B. Cros ${ }^{1,2}$ \\ ${ }^{1}$ Université de Toulouse, UPS, LA (Laboratoire d'Aérologie), 14 avenue Edouard Belin, 31400 Toulouse, France \\ ${ }^{2}$ CNRS, LA (Laboratoire d'Aérologie), UMR 5560, 31400 Toulouse, France \\ ${ }^{3}$ Faculté des Sciences, Université Marien NGouabi, BP 2702 Brazzaville, Congo \\ *now at: LGIT (Laboratoire de Géophysique Interne et Technophysique), BP 53, 38041 Grenoble, Cedex 09, France
}

Received: 28 July 2009 - Published in Atmos. Chem. Phys. Discuss.: 6 October 2009

Revised: 17 December 2009 - Accepted: 17 December 2009 - Published: 1 February 2010

\begin{abstract}
This paper reports the first record of extreme ozone measurements in Africa. As part of the AMMA program, the ozone vertical profile recorded on 20 December over Cotonou presents exceptionally high ozone concentrations with up to $295 \mathrm{ppb}$ at $1 \mathrm{~km}$ altitude. Retroplumes from the Flexpart model show that the air masses sampled at $1 \mathrm{~km}$ over Cotonou on this day came from the burning area situated north-east of Cotonou and passed over Lagos, Nigeria, which is highly impacted by urban pollution. We used the Master Mechanism box model to simulate the chemical composition of the plume during its transit.

We find that neither the biomass burning emissions of ozone precursors nor additional urban emissions from Lagos are high enough to simulate more than $120-150 \mathrm{ppb}$ of ozone. The only way to reach almost $300 \mathrm{ppb}$ of ozone within a few hours is to feed the air mass with large amounts of reactive VOCs as those recorded in the vicinity of petrochemical area. Sensitivity tests show that 250-600 ppb of VOCs combined with 35-80 ppb of $\mathrm{NO}_{\mathrm{x}}$ allow the ozone concentrations to be higher than $250 \mathrm{ppb}$. Nigeria is the first African country with gas extraction and petrochemical industries, and petrochemical explosions frequently happen in the vicinity of Lagos. The hypothesis of a petrochemical explosion in this area is the most likely scenario which could explain the $295 \mathrm{ppb}$ ozone maximum measured over Cotonou, downwind of Lagos.
\end{abstract}

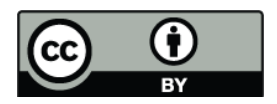

Correspondence to: V. Thouret (valerie.thouret@aero.obs-mip.fr)

\section{Introduction}

Tropospheric ozone is an important trace gas regarding its role in the oxidative capacity of the global atmosphere, its climate effect and its impact on air quality. Two main reasons make the tropical regions of interest regarding tropospheric ozone. Firstly, photochemistry and $\mathrm{OH}$ formation are more active in the tropics due to high UV radiation and humidity. Secondly, the tropics are important source regions of ozone precursors, especially through biomass burning (Andreae and Merlet, 2001; van der Werf et al., 2006), biogenic (Guenther et al., 1995, 2006; Serça et al., 1998; Jaeglé et al., 2004, 2005; Aghedo et al., 2007) and lightning emissions (Moxim and Levy, 2000; Sauvage et al., 2007; Höller et al., 2009). In addition, some of the biggest cities in the world are situated in tropical regions (e.g. Lagos, Mexico city, Bangkok, Bombay). These cities are subject to increasing anthropogenic emissions and suffer air quality problems. Air quality in the megacities is quite a recent issue in our scientific field. Lawrence et al. (2007) emphasized the role of megacities in controlling the pollution at regional scales. Butler et al. (2008) questioned the representation of the emissions of the megacities in global models and pointed out large differences between available inventories.

Several African campaigns from TROPOZ in 1987 to TRACE-A and SAFARI in 1992 and SAFARI in 2000 have highlighted the importance of the tropical region, and particularly Africa, as a source region of ozone precursors (e.g., Cros et al., 1992, 2000; Delmas et al., 1999; Jonquière et al., 1998; Jacob et al., 1996; Thompson et al., 1996; Swap et al., 2003). However, these programs did

Published by Copernicus Publications on behalf of the European Geosciences Union. 


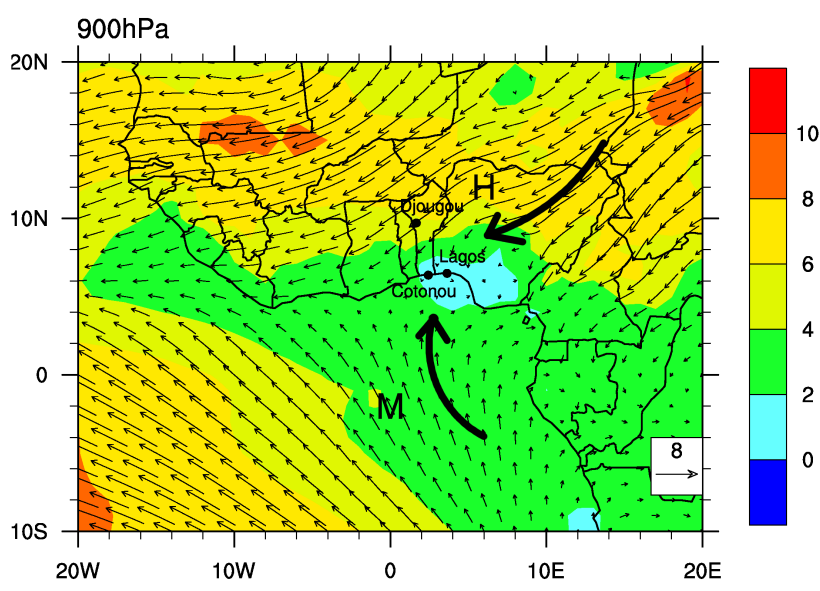

Fig. 1. Horizontal cross section over West Africa at $900 \mathrm{hPa}$ giving wind speed and wind directions along with the schematic arrows for the harmattan and monsoon flux (black arrows), as well as the position of Cotonou, Djougou and Lagos.

not specifically address air quality issues in African cities. Few studies were dedicated to this issue in Sub-Saharan cities. For example, Baumbach et al. (1995); Fanou et al. (2006); Linden et al. (2008) show exposure situations that exceed World Heath Organization (WHO) standards in Lagos (Nigeria), Cotonou (Benin) and Ouagadougou (Burkina Faso), respectively. More recently, the African Monsoon Multidisciplinary Analysis (AMMA) program aimed at documenting the chemical composition of the West African atmosphere and its variations linked to dynamics and climate. Indeed, Hopkins et al. (2009) presented a first analysis of in situ data recorded over the city of Lagos during an aircraft flight dedicated to anthropogenic pollution. In the frame of AMMA, an ozone sounding station was set up in Cotonou, Benin $\left(6.21^{\circ} \mathrm{N}, 2.23^{\circ} \mathrm{E}\right)$ thanks to the IRD (Institut de Recherche et Développement) and the SMN/ASECNA (Service Météorologique National/Agence de securité et de navigation aérienne) people located there. These regular soundings were performed between December 2004 and January 2007 and aimed to better assess the seasonal and interannual variability of ozone vertical profiles in Equatorial Africa as described by Thouret et al. (2009). They found that December 2005 was characterized by very high ozone concentrations throughout the troposphere compared to the rest of the sampled period. Also, the vertical profile obtained on 20 December 2005 that they presented shows exceptionally high ozone concentrations in the lower troposphere. Ozone concentrations almost reached $300 \mathrm{ppb}$ at around $1000 \mathrm{~m}$ altitude on this day. As far as we know, such extreme concentrations have never been recorded in the lower troposphere over Africa before. The highest ozone concentration ever reported in the literature has been measured in the metropolitan area of Mexico city with more than $300 \mathrm{ppb}$ (West et al., 2004). Similar concentrations have also been recorded in polluted plumes originating from Beijing (286 ppb, Wang et al., 2006), from Houston (238-251 ppb, Berkowitz et al., 2004, Kleinman et al., 2002), from Mexico city (243-250 ppb, deFoy et al., 2005; Tie et al., 2007; Molina et al., 2007) and from the Po valley in Italy (200 ppb, Spirig et al., 2002). The lack of measurements dedicated to air quality or pollution episodes did not allow the exploration of such phenomenon in Africa. We report here the first extreme values of ozone concentration ever measured in this Sub-Saharan region.

The objectives of this paper are to present the extreme ozone concentrations recorded on 20 December 2005 in the lower troposphere and to suggest an hypothetic scenario, which explains how near $300 \mathrm{ppb}$ concentrations of ozone can be produced in the vicinity of Cotonou. The radiosounding data and the synoptic situation in December 2005 are presented in Sect. 2. The ozone anomaly is further detailed in Sect. 3. Section 4 presents the Master Mechanism (hereafter MM) box model we used for this analysis along with the possible scenario. The different hypothesis are discussed in Sect. 5 where we finally propose the most likely scenario.

\section{Data presentation and meteorological situation}

\subsection{Data acquisition}

Three soundings have been launched in December 2005 (on 16, 20 and 22 around 10:00 UTC). The ozone measurements were made with balloon-borne ECC (Electrochemical Concentration Cell) ozonesondes coupled with a standard radiosonde including a sensor for relative humidity and temperature. We used the Vaisala manufactured RS80 radiosondes during the entire AMMA period. The air for the ozone measurements was sampled with a Science Pump 6A type. Further details on the entire data set along with quality and accuracy of ozone data can be found in Thouret et al. (2009).

\subsection{Observation sites}

Cotonou, located on the coast of the Gulf of Guinea is the economic capital of Benin with a population of 1.2 million inhabitants (data from 2008). The city is situated $110 \mathrm{~km}$ east of Lagos $\left(6.3^{\circ} \mathrm{N}, 3.2^{\circ} \mathrm{E}\right)$, which is the economic capital of Nigeria. The location of these two cities is shown on Fig. 1. Lagos is the most populated city in West Africa and one of the biggest cities in the world, with more than 13 million people over only $3577 \mathrm{~km}^{2}$. The biggest power plant of the northern hemisphere part of Africa is situated in Lagos. Also, Lagos hosts around $75 \%$ of the commercial and industrial activities of the country (Hopkins et al., 2009), including petrochemical activities.

The confluence of the Harmattan and the monsoon flux is the main characteristic of the region in terms of synoptic situation. This latter has been described in previous papers such as Sauvage et al. (2005) and many references of this special 


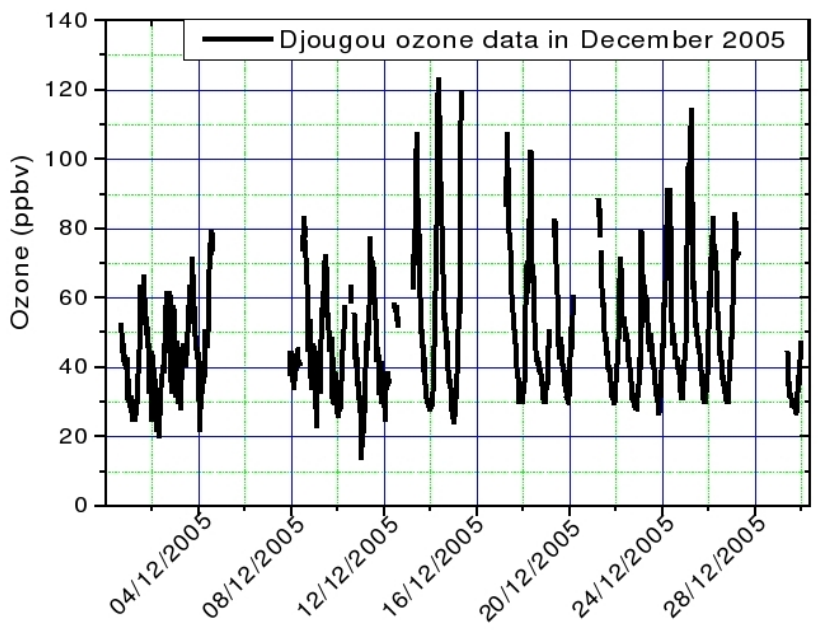

Fig. 2. Time evolution of the ozone concentrations measured at the ground based station Djougou during December 2005.

issue. A nice schematic zonal vertical cross section has also been proposed by Haywood et al. (2008) (their Fig. 12). Figure 1 shows this main characteristic by representing the average wind speed and direction at $900 \mathrm{hPa}$ over West Africa in December 2005, based on ECMWF analysis. At this altitude, in December, the coast of the Gulf of Guinea is under the influence of the Harmattan flux from north-east and under the one of the monsoon flux from south-west as shown by the black arrows. It is also worth noting the very low wind speed in the region around Cotonou and Lagos.

The December month corresponds to the dry season during wich biomass burning occurs all over the Soudano Guinean band between 8 and $12^{\circ} \mathrm{N}$ (Sauvage et al., 2005; Thouret et al., 2009). Consequently, at this time of the year, the ozone vertical profiles over Cotonou and Lagos are characterized by enhanced ozone concentrations (up to 70 or $80 \mathrm{ppb}$ on monthly average) in the Harmattan layer (between 1 and $3 \mathrm{~km}$ altitude).

Ozone concentrations were measured at the ground based station of Djougou, about $400 \mathrm{~km}$ north of Cotonou also as part of the AMMA program (Fig. 1). Djougou is situated in the middle of the burning area and is under the influence of the Harmattan flux. This site is representative of the Soudano Guinean region and the measurements made there give typical values of the chemical composition of the air masses impacted by biomass burning during the dry season. Figure 2 gives the time series of the ozone concentrations recorded at Djougou in December 2005. Ozone concentrations greater than $100 \mathrm{ppb}$ were measured several days in a row $(14,15$, $16,18,19$ and 26) with peaks at 123 and $120 \mathrm{ppb}$ on the 15 and 16 , respectively.

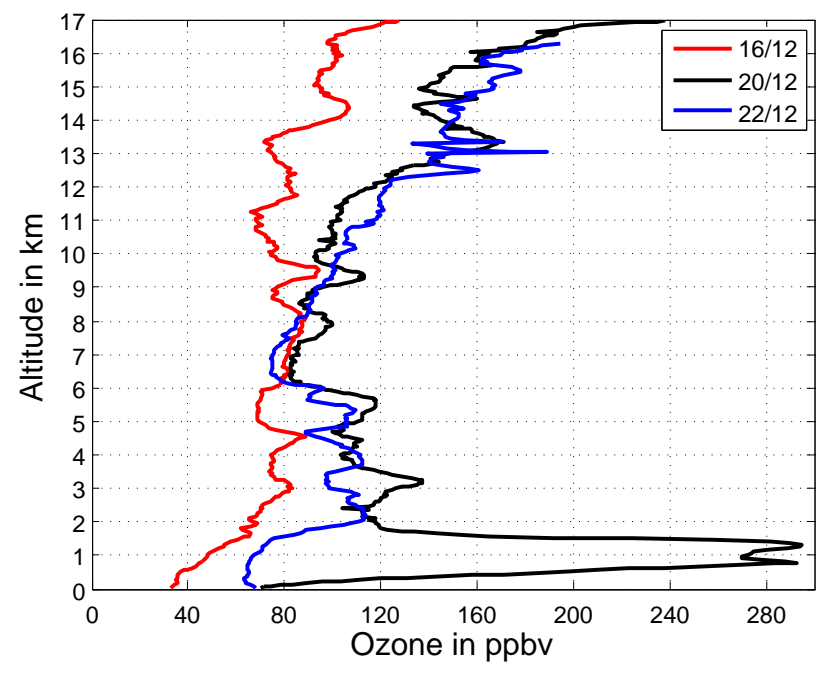

Fig. 3. Vertical profiles of ozone up to $17 \mathrm{~km}$ over Cotonou provided by the three soudings performed in December 2005: on 16 (red), 20 (black) and 22 (blue).

\section{Case study of 20 December}

Figure 3 presents the three vertical profiles recorded in December 2005 over Cotonou. Only the tropospheric part (up to $17 \mathrm{~km}$ ) is shown. Based on satellite and ozone sounding data, Thouret et al. (2009) have shown that December 2005 is characterized by relatively high ozone concentrations throughout the whole troposphere compared to the entire period of December 2004-January 2007. In the middle troposphere, the three profiles show similar ozone concentrations with values around $90 \mathrm{ppb}$ between 6 and $10 \mathrm{~km}$. The two profiles on the 20 and 22 December 2005 are very similar above $2 \mathrm{~km}$ and both of them show concentrations close to $70 \mathrm{ppb}$ at the surface. This value is the overall maximum of surface concentrations within the radiosounding data set. The most impressive feature of this figure is the ozone enhanced layer peaking at around $1 \mathrm{~km}$ altitude on the profiles of $20 \mathrm{De}-$ cember. This layer is about $1.5 \mathrm{~km}$ thick and ozone concentrations are up to almost $300 \mathrm{ppb}$. Figure 4 presents the vertical profiles of ozone, temperature and relative humidity between the ground and $3 \mathrm{~km}$ altitude. This shows that the highly polluted plume is lying inside the boundary layer, which is capped by the temperature inversion and the strong decrease in humidity (the Harmattan layer above is drier than the monsoon layer below), characterizing thus the difference in stability and preventing the vertical mixing. Thouret et al. (2009) have demonstrated the quality of this entire data set. Both Figs. 3 and 4 give further evidence that such ozone enhanced layer is not an erroneous measurement. Profiles on the 20 and 22 December are very similar at the surface and above $2 \mathrm{~km}$ altitude. Besides, the ozone sonde measured an ozone layer in physical agreement with the thermodynamical characteristics which were measured by the independent PTU sonde, this one being not controversial. 
Table 1. Tropospheric columns of ozone from the surface up to $17 \mathrm{~km}$ and contributions of the $0-2 \mathrm{~km}$ and $2-17 \mathrm{~km}$ layers in Dobson Unit. These ozone amounts are calculated for the three individual soundings of December 2005 (16, 20, 22), the mean vertical profile of December 2005 and the mean vertical profile of December from years 2004, 2005 and 2006 (called mean AMMA).

\begin{tabular}{lccccc}
\hline Columns (DU) & 16 Dec 2005 & 20 Dec 2005 & 22 Dec 2005 & mean Dec 2005 & mean AMMA \\
\hline TCO $(0-17 \mathrm{~km})$ & 52.5 & 94.9 & 70.7 & 66.3 & 50.3 \\
$0-2 \mathrm{~km}$ & 8.0 & 32.1 & 11.9 & 9.3 & 8.2 \\
$2-17 \mathrm{~km}$ & 44.5 & 62.8 & 58.8 & 57.0 & 42.0 \\
\hline
\end{tabular}
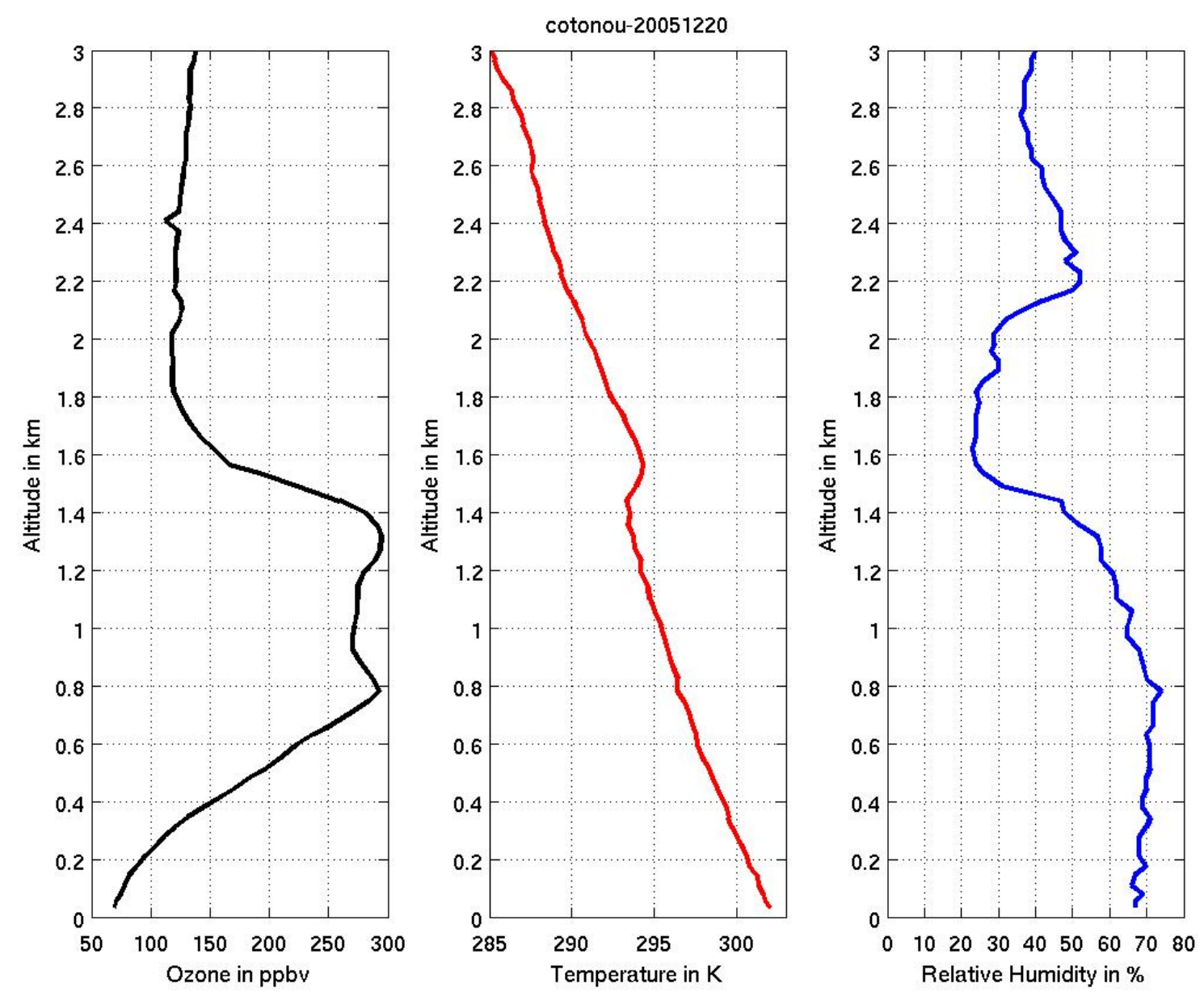

Fig. 4. Vertical profiles of ozone in ppb (left), temperature in $\mathrm{K}$ (center), relative humidity in \% (right) between the ground and $3 \mathrm{~km}$ altitude as measured on 20 December 2005 over Cotonou.

Such high ozone concentrations have never been sampled before in this region. The MOZAIC program (Marenco et al., 1998, Sauvage et al., 2005) provide quite a large sampling of the ozone distribution over Lagos, Nigeria between 1997 and 2004. Figure 5 gives the scatter plot of all the MOZAIC measurements over Lagos during this period. The ozone concentrations in the MOZAIC data set maximize at $120 \mathrm{ppb}$ of ozone between 800 and $900 \mathrm{hPa}$. Concentrations as high as those recorded on 20 December over Cotonou have never been recorded during the seven years of operations of MOZAIC over West Africa (i.e. 361 flights).

To better assess how large the discrepancies are on 20 December 2005 compared to other sampled December months, we calculate the tropospheric column of ozone (TCO) as well as the contributions of the $0-2 \mathrm{~km}$ and $2-17 \mathrm{~km}$ layers. Table 1 gives these ozone amounts in Dobson unit for the three individual ozone profiles of December 2005, the mean of December 2005 and the average of December 2004, 


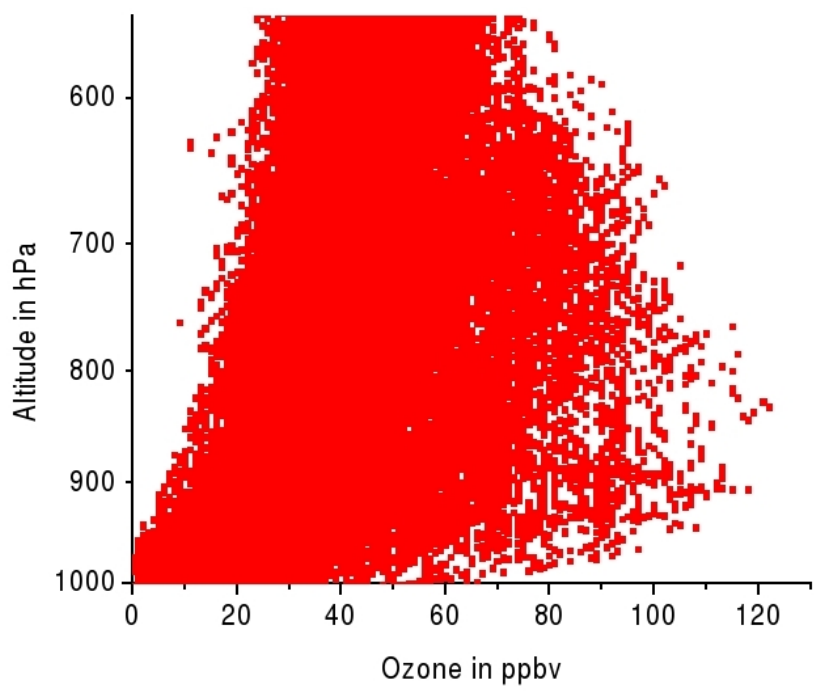

Fig. 5. Scatter plots of ozone over Lagos based on 361 MOZAIC vertical profiles.

ECMWF Wind direction - Lon 2.517 - 900hPa

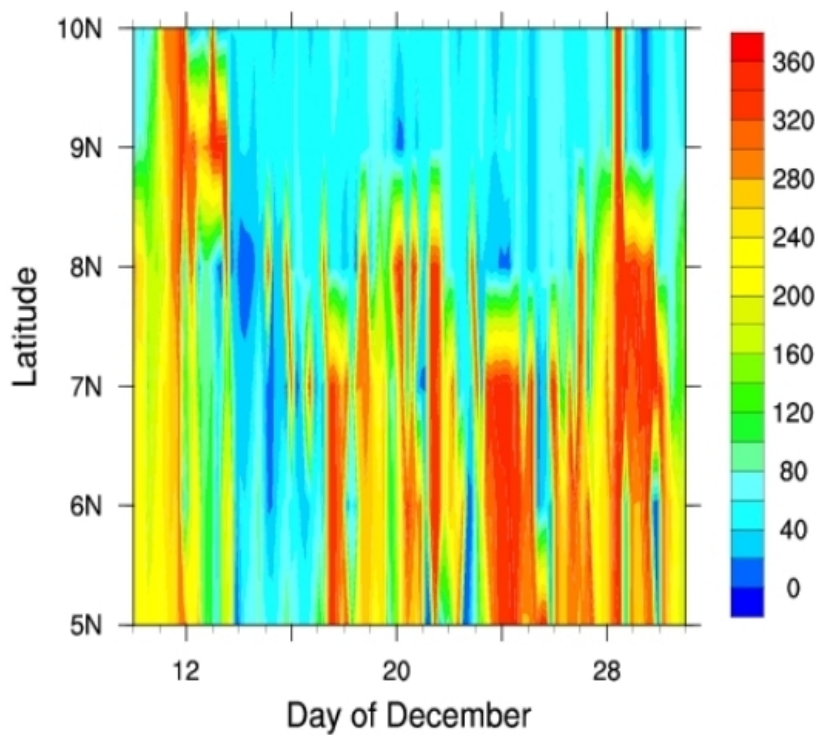

Fig. 6. Hovmoeller diagram of the wind direction (degrees) at $900 \mathrm{hPa}$ at the longitude of Cotonou $\left(2.5^{\circ} \mathrm{E}\right)$ from ECMWF analysis.

December 2005 and December 2006. The TCO on 20 December 2005 is almost twice as large as a standard day (16 December 2005 for example). The $0-2 \mathrm{~km}$ layer accounts for almost $35 \%$ of the TCO on this day and is three to four times larger than usually observed at this altitude showing how exceptional the event is.

Figures 6 and 7 give the temporal variations of the wind direction and speed, respectively, at $900 \mathrm{hPa}$ between 5 and $10^{\circ} \mathrm{N}$ at the longitude of Cotonou during December 2005.
ECMWF Wind speed - Lon 2.517 - 900hPa

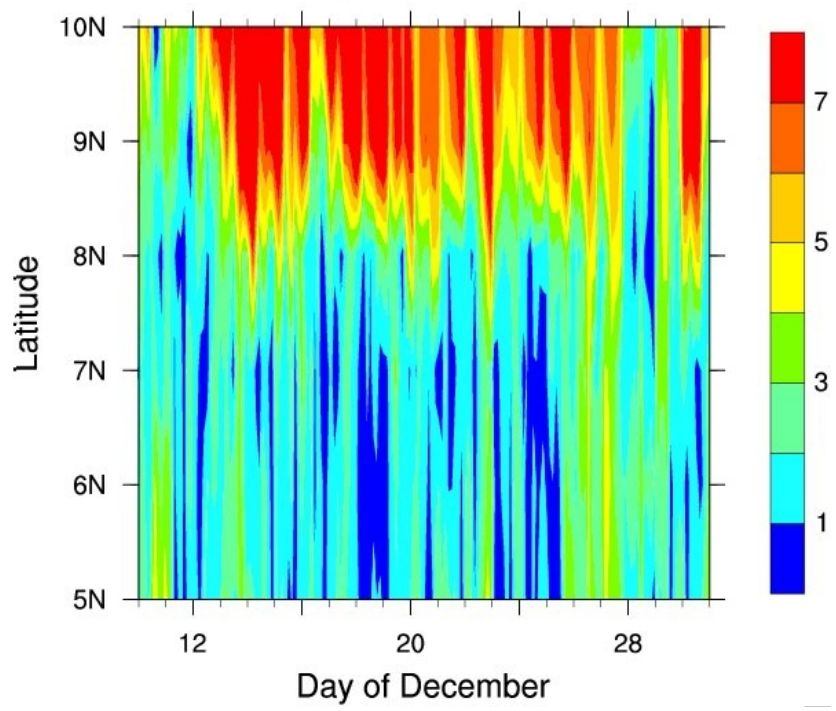

Fig. 7. Hovmoeller diagram of the wind speed $\left(\mathrm{m} \mathrm{s}^{-1}\right)$ at $900 \mathrm{hPa}$ at the longitude of Cotonou $\left(2.5^{\circ} \mathrm{E}\right)$ from ECMWF analysis.

Data are computed from ECMWF analysis. If we look at the latitude of Cotonou $\left(6.2^{\circ} \mathrm{N}\right)$, we can see that the wind patterns are different between the 16 and the 20-22 December 2005 . Around the 16th, the Harmattan flow (wind direction between 30 and $80^{\circ}$ ) is well established. On the contrary, on the 20 and 22 the monsoon flow (wind direction between 120 and $240^{\circ}$ ) still prevails, especially on the 20 . Also, the 20 December 2005 as well as the 18 and 19 December are characterized by a particularly very slow southeastern wind, less than 1 or $2 \mathrm{~m} \mathrm{~s}^{-1}$. This suggests that there can be an accumulation of pollutants in stagnant air masses in the region of Cotonou and Lagos and also indicates that an additional urban source of ozone and ozone precursors from Lagos might interfere and favour ozone photochemical production during the travel of the plume between Lagos and Cotonou.

\section{Hypothetical scenario}

Such high ozone concentrations, within the boundary layer, are obviously not of stratospheric origin. If there were a stratospheric influence, the air mass would have lost its stratospheric ozone characteristics as it has lost its water vapor characteristics (the layer is also quite wet with $70 \%$ of RH). According to backward trajectory analysis using the FLEXPART lagrangian model (Stohl et al., 2005), the air masses in which very high ozone concentrations were measured on 20 December 2005 originated mainly from the northeast (Fig. 8). These air masses were over the burning area three days before in agreement with Sauvage et al. (2005). Our FLEXPART results show that the air masses 

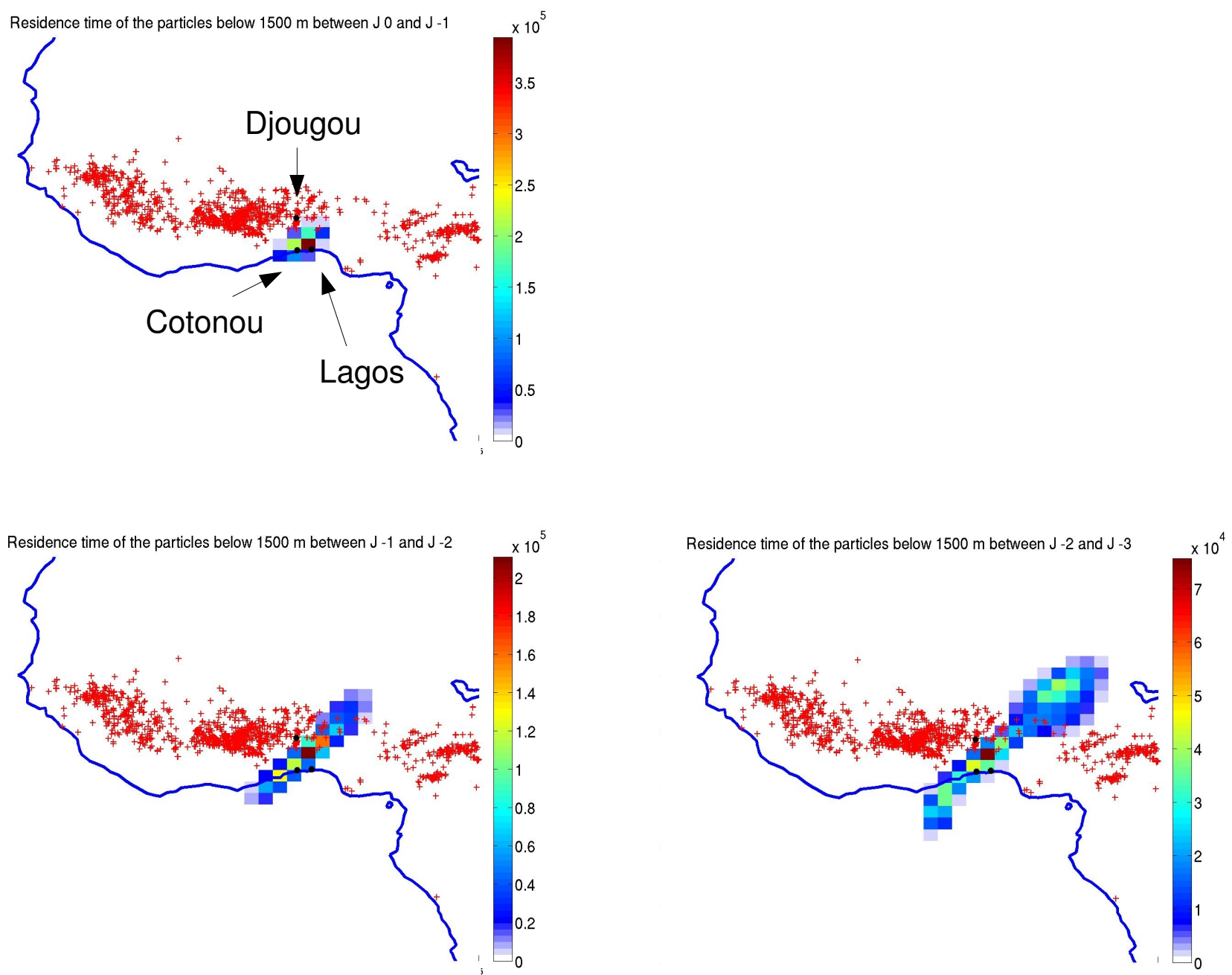

Fig. 8. Retroplumes calculated by the FLEXPART model for the first $24 \mathrm{~h}$ (top panel), between 24 and $48 \mathrm{~h}$ (bottom left), and between 48 and $60 \mathrm{~h}$ (bottom right) initialised over Cotonou in the ozone enhanced layers (between 800 and $1600 \mathrm{~m}$ ) measured on the 20 December 2005. Black dots mark the position of Cotonou, Djougou and Lagos. Red crosses mark the position of active fires as detected by MODIS on the 16, 17, 18 and 19 December 2005.

have been rather stagnant between Lagos and Cotonou for more than one day. A further detailed analysis shows that most of the air particules stay, indeed, in the same range of altitude, $800-1500 \mathrm{~m}$. The wind speed in the vicinity of Cotonou and Lagos was less than $2 \mathrm{~m} \mathrm{~s}^{-1}$, meaning that air masses needed around $15 \mathrm{~h}$ to travel from Lagos to Cotonou and could be influenced by local pollution from Lagos.

We propose here a scenario that could explain this extreme and rare pollution event. As seen from the literature and from Figs. 2 and 5, ozone concentrations in biomass burning plumes seem to maximize around $120 \mathrm{ppb}$ but not more in West Africa. To produce the additional $180 \mathrm{ppb}$ to reach the $300 \mathrm{ppb}$, the air mass needed to be fed with fresh $\mathrm{NO}_{\mathrm{x}}$ and reactive precursors such as volatil organic compounds (VOCs). Table 2 gives a non exhaustive overview of the ozone concentrations along with the ozone production rate and the associated gaseous pollutants measured in different urban areas known for their episodes of high pollution. For example, ozone concentrations as high as $251 \mathrm{ppb}$ have been measured over Houston associated with high concentrations of ethene, propene and butene.

The Master Mechanism zero-dimensional model (Madronich and Calvert, 1990) has been used to investigate the photochemical production of ozone in the region, one, two or three days before 20 December 2005. The Master Mechanism model consists of a detailed gas phase photochemistry, with nearly 5000 reactions between nearly 2000 species. This model computes the time-dependent chemical evolution of an air parcel initialized with known composition, assuming no additional emissions and no heterogeneous processes. Photolysis frequencies are computed from the TUV model (Madronich and Flocke, 1998) every 
Table 2. Non-exhaustive list of studies reporting events of high ozone concentrations. The ozone concentrations and production rates as well as the concentrations of some ozone precursors are given.

\begin{tabular}{|c|c|c|c|c|}
\hline References & Region & Ozone (ppb) & Ozone prod. rate $\left(\mathrm{ppb}^{-1}\right)$ & gaseous pollutants (ppb) \\
\hline Wang et al. (2006) & Beijing metropolitan area & $180-286$ & $\mathrm{NC}$ & $\begin{array}{l}\mathrm{CO}(500-2000) \\
\mathrm{NO}_{\mathrm{y}}(12-60) \\
\mathrm{SO}_{2}(4-60)\end{array}$ \\
\hline Spirig et al. (2002) & Po Valley (Italia) & $150-200$ & $20-30$ & $\begin{array}{l}\mathrm{NO}_{\mathrm{x}}(8-14) \\
\mathrm{CO}(500-600) \\
\mathrm{C}_{6} \mathrm{H}_{6}(1.5-2.5) \\
\mathrm{CH}_{2} \mathrm{O}(5.2-10) \\
\mathrm{NO}_{\mathrm{y}}(37-47)\end{array}$ \\
\hline Kleinman et al. (2005) & Houston area & $151-211$ & $25-140$ & $\begin{array}{l}\mathrm{NO}(5-25) \\
\mathrm{NO}_{\mathrm{x}} \text { gt } 100 \\
\text { Isoprene }(0.01-10.2)\end{array}$ \\
\hline Kleinman et al. (2002) & Houston area & $124-251$ & $5-45$ & $\begin{array}{l}\mathrm{NO}_{\mathrm{x}}(1-40) \\
\text { Ethene }(16) \\
\text { Propene }(8) \\
\text { Butene }(2.5)\end{array}$ \\
\hline Zhang et al. (2007) & Hong Kong area & $120-203$ & $\mathrm{NC}$ & $\begin{array}{l}\mathrm{NO}_{\mathrm{x}}(20-60) \\
\mathrm{NO}_{\mathrm{y}}(2-150) \\
\mathrm{NO}(0.01-100) \\
\mathrm{SO}_{2}(1-70) \\
\mathrm{CO}(400-3500) \\
\mathrm{VOC}(20-900) \\
\text { aromatic hydrocarbons }(19-205)\end{array}$ \\
\hline Berkowitz et al. (2004) & Houston area & $205-238$ & $\mathrm{NC}$ & $\begin{array}{l}\mathrm{NO}(122) \\
\mathrm{NO}_{\mathrm{y}}(59-146) \\
\mathrm{CO}(670-1100) \\
\mathrm{HCHO}(20-40) \\
\mathrm{SO}_{2}(40-58) \\
\mathrm{HNO}_{3}(3.7-8) \\
\mathrm{PAN}(3.6-15.9)\end{array}$ \\
\hline Guangfeng and Fast (2004) & Houston area & 20-200 & $10-35$ & $\begin{array}{l}\mathrm{HCHO}(1-34) \\
\text { Ethene }(1-82) \\
\text { Toluene }(1-5) \\
\mathrm{NO}_{\mathrm{x}}(0-50)\end{array}$ \\
\hline Hung-Lung et al. (2007) & Taiwan area & $10-100$ & $\mathrm{NC}$ & 52 VOC species (110-190) \\
\hline
\end{tabular}

15 min. The dilution of the air parcel with the ambient air has been included in the model following the formulation of Arnold et al. (2007): mixing is simulated using background concentrations from MOZAIC and AMMA database and a typical lifetime of the air parcel. All runs are done with a 5 days and a 10 days lifetime as determined in Arnold et al. (2007) and the background concentrations used are given in Table 3. This model cannot substitute a full 3-D Chemistry-Transport Model (CTM), but has the advantage of describing explicitly all intermediate chemical transformations (Madronich, 2006), which is necessary to describe such an extreme event. The calculated concentrations are not meant to be the exact values recorded but rather to give an order of magnitude of the ozone amount that can be produced from various chemical mixtures. The meteorological forcing is taken from the sounding data in the altitude of the ozone enhanced layer. For example, temperature and relative humidity are set, respectively, at $295 \mathrm{~K}$ and $70 \%$, and are constant throughout the simulation. This is justified by the fact that air masses are travelling mostly between 800 and $1500 \mathrm{~m}$ as realed by the Flexpart analysis (Fig. 8). Besides, even if ozone production efficiency varies with temperature, we rather want to focus on the role of precursors emissions. The ozone concentration in the air mass has been initialized 
Table 3. Ozone precursors concentrations used to initialize the three runs (Biomass burning, Additional Lagos and Additional petrochemical accident) performed with the Master Mechanism box model (Madronich and Calvert, 1990) and backgound concentrations used to compute the mixing of the air parcel. Empty spaces mean that concentrations are taken from the restart run without modifications.

\begin{tabular}{|c|c|c|c|c|}
\hline Compounds (ppb) & Biomass burning $^{\mathrm{a}}$ & Add. Lagos ${ }^{\mathrm{b}}$ & Add. petrochemical accident ${ }^{\mathrm{c}}$ & Bgd concentrations ${ }^{\mathrm{d}}$ \\
\hline NMHC (listed below) & 36.55 & 16.8 & 280 & \\
\hline $\mathrm{C}_{2} \mathrm{H}_{4}$ (Ethene) & 10 & 1.4 & 50 & \\
\hline $\mathrm{C}_{3} \mathrm{H}_{6}$ (Propene) & 10 & 1.4 & 40 & \\
\hline $\mathrm{C}_{2} \mathrm{H}_{6}$ (Ethane) & 10 & 1.2 & 40 & \\
\hline $\mathrm{C}_{3} \mathrm{H}_{8}$ (Propane) & 0.5 & 0.3 & 20 & \\
\hline $\mathrm{C}_{6} \mathrm{H}_{6}$ (Benzene) & 5 & 1 & 30 & \\
\hline $\mathrm{C}_{2} \mathrm{H}_{2}$ (Acetylene) & 0.5 & 1.8 & 40 & \\
\hline $\mathrm{C}_{4} \mathrm{H}_{10}$ (Butane) & 0.5 & 1.3 & 20 & \\
\hline $\mathrm{C}_{7} \mathrm{H}_{8}$ (Toluene) & 0.05 & 1 & 40 & \\
\hline Carbonyl compounds (listed below) & 1.5 & 11.4 & 40.5 & \\
\hline HCHO (Formaldehyde) & 0.5 & 3.4 & 10 & \\
\hline $\mathrm{CH}_{3} \mathrm{COOH}$ (Acetic acid) & 0.5 & 0.5 & 0.5 & \\
\hline $\mathrm{CH}_{3} \mathrm{COCH}_{3}$ (Acetone) & 0.5 & 1.6 & 20 & \\
\hline $\mathrm{CH}_{3} \mathrm{CHO}$ (Acetaldehyde) & 0 & 6 & 10 & \\
\hline $\mathrm{O}_{3}$ (ozone) & 50 & & & 60 \\
\hline $\mathrm{NO}_{\mathrm{x}}$ (Nitrogen oxide $)$ & 40 & 6 & 55 & 0.5 \\
\hline $\mathrm{CH}_{4}$ (methane) & 1981 & & & 1980 \\
\hline $\mathrm{CO}$ (carbon monoxyde) & 1000 & & & 450 \\
\hline $\mathrm{SO}_{2}$ (sulfur dioxide) & 5 & & 10 & 1 \\
\hline $\mathrm{NH}_{3}$ (ammonia) & 5 & & 10 & 1 \\
\hline
\end{tabular}

a taken from Poppe et al. (1998)

$\mathrm{b}$ taken from Hopkins et al. (2009)

c Adapted from our sensitivity study (Fig. 10) and from the literature as presented in Table 2 .

d Adapted from MOZAIC measurements for $\mathrm{CO}$ and $\mathrm{O}_{3}$, from Carmichael et al. (2003) for $\mathrm{NH}_{3}$ and $\mathrm{SO}_{2}$ and from Stewart et al. (2008) for $\mathrm{NO}_{\mathrm{X}}$.

at $50 \mathrm{ppb}$ which is the long-term average background value at this time of the year in this region. For the simulations, we have used the time frame resulting from the back trajectories shown in Fig. 8. The air mass travels from the biomass burning area to the vicinity of Lagos during 24 to $48 \mathrm{~h}$ and afterwards takes about $15-18 \mathrm{~h}$ to reach Cotonou, where high ozone concentrations were measured.

The first set of runs is called "Biomass Burning" and gives the chemical composition of the air mass after passing over a fire of biomass in West African savanna for two typical value of the air parcel lifetime: 10 days and 5 days. Even though we set up the runs to last for $42 \mathrm{~h}$ (beginning 12:00, end 06:00 LT, 2 days after) to be consistent with the back trajectories analysis (Fig. 8), Fig. 9a shows a $100 \mathrm{~h}$ lasting runs in order to exhibit the two peaks of ozone production followed by a weak decreasing mainly explained by dilution. This run is initialized according to concentrations that are characteristic of a savanna fire as described by Poppe et al. (1998). Table 3 gives the amount of the NMHCs (which contain ethene, propene, ethane, benzene, propane, acetylene, butane, toluene $), \mathrm{NO}_{\mathrm{x}}\left(=\mathrm{NO}+\mathrm{NO}_{2}\right)$, and carbonyl compounds (which contain formaldehyde, acetic acid, acetone and acetaldehyde) used for this Biomass Burning run and the runs described below. Figure 9 (top) presents the results from this first set of runs and shows that $\mathrm{NO}_{\mathrm{x}}$ decreases from $40 \mathrm{ppb}$ to a few ppt after $35 \mathrm{~h}$ of simulation. CO concentrations decreases by $100 \mathrm{ppb}$ per day for the 10 days dilution run and by $160 \mathrm{ppb}$ per day for the 5 days dilution run due to a combined effect of oxidation and dilution during the day and the effect of dilution during the night. The ozone concentrations reach a peak value of $100 \mathrm{ppb}$ for the 10 days dilution run and of $110 \mathrm{ppb}$ for the 5 days dilution run the second day, which is what we expect to be typical of the biomass burning plumes in agreement with the measurements from Djougou or from MOZAIC-Lagos (Figs. 2 and 5, respectively).

The second set of runs is called "Additional Lagos", and simulates the passing of the air mass already charged in biomass burning compounds over Lagos for a air parcel lifetime of 10 days and 5 days. It begins at 06:00 UTC local time and lasts for 3 days $(72 \mathrm{~h}) . \mathrm{NO}_{\mathrm{x}}, \mathrm{NMHC}$ and carbonyl 


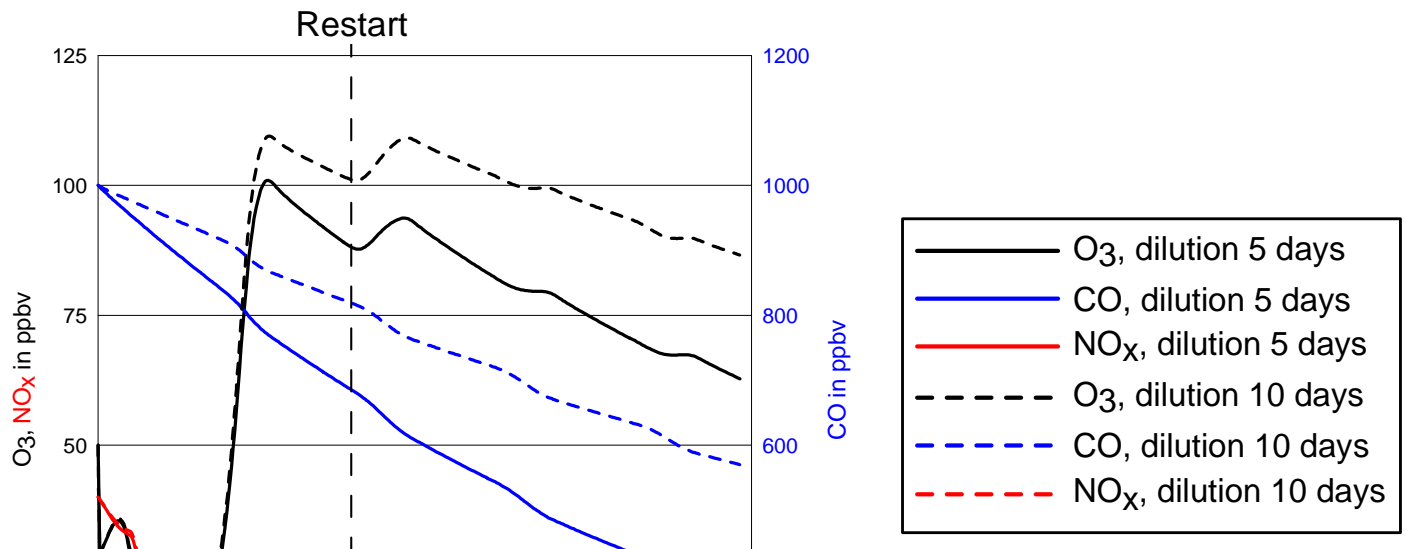

(a)
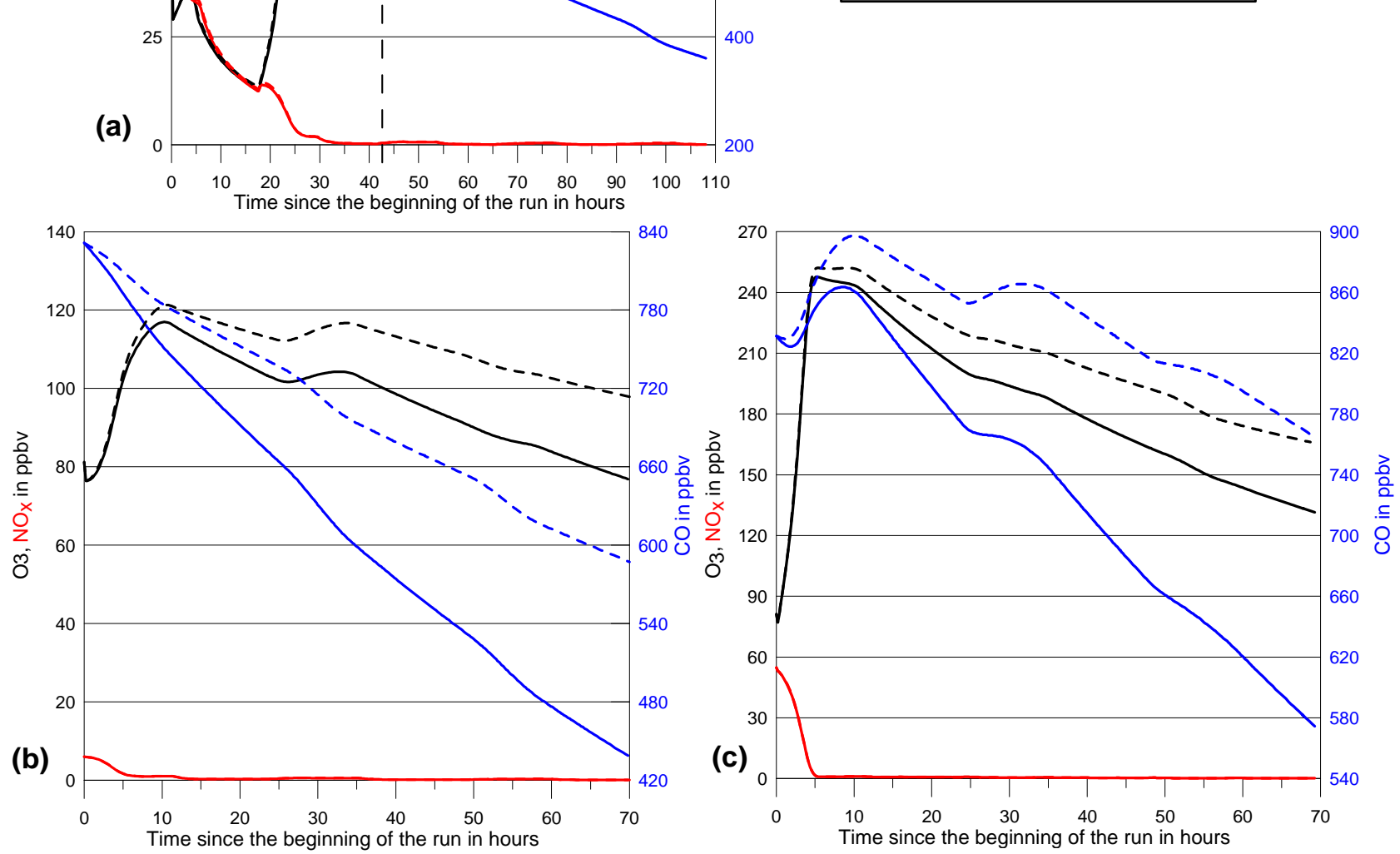

Fig. 9. Time evolution of the ozone (black), $\mathrm{CO}$ (blue) and $\mathrm{NO}_{\mathrm{x}}$ (red) concentrations simulated by the Master Mechansim box model for the three simulations: (a) biomass burning, (b) additional Lagos and (c) additional petrochemical accident.

compunds are re-initialized. For other compounds including $\mathrm{CO}$ and ozone, concentrations at the beginning of this second set of simulations are those calculated in the Biomass Burning runs after $42 \mathrm{~h}$ for the two dilution hypothesis (10 days and 5 days). Additional fuel from Lagos urban emissions provides fresh VOCs and $\mathrm{NO}_{\mathrm{x}}$. We used the concentrations measured over Lagos on board the BAe-147 during the AMMA campaign (Hopkins et al. (2009), C. Reeves personal communication, 2009). These concentrations are given in Table 3. Our case study is in December 2005 but we assume there is no significant seasonal variation for the anthropogenic emissions. This set of runs shows that ozone concentrations reach peak value around $120 \mathrm{ppb}$ after a few hours (Fig. 9b) and slightly decrease due to dilution to about $100 \mathrm{ppb}$ for the 10 days dilution run and to about $80 \mathrm{ppb}$ for the 5 days dilution run after 3 days of simulation. These results show that anthropogenic emissions from urban pollution in Lagos is not sufficient to produce enough ozone downwind and explain the near $300 \mathrm{ppb}$ of ozone as measured in Cotonou.

Several studies have been conducted in the region of Houston, where petrochemical industries emit a large amount of VOCs and $\mathrm{NO}_{\mathrm{x}}$ in the atmosphere (Kleinman et al., 2005; Berkowitz et al., 2004; Guangfeng and Fast, 2004), as well 


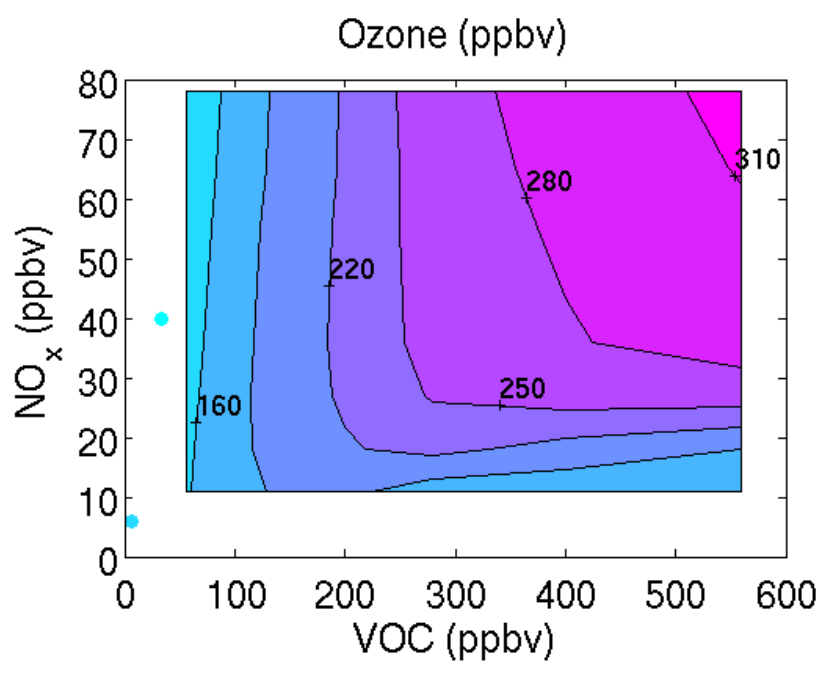

Fig. 10. Isopleths of the ozone concentrations as a function of $\mathrm{NO}_{\mathrm{x}}$ and VOCs concentrations. This is interpolated from the calculation of 49 sensitivity tests using the box model as done for the so called additional petrochemical accident run.

as in Asian petrochemical complexes (Zhang et al., 2004; Hung-Lung et al., 2007). High ozone concentrations have been measured downwind petrochemical industrial facilities, where highly elevated concentrations of $\mathrm{NO}_{\mathrm{x}}$ (much more elevated than in urban zones) and reactive VOCs are simultaneously present (Ryerson et al., 2003). Usual ozone concentrations in Houston reported in Ryerson et al. (2003) remain half the ones measured in Cotonou the 20 December 2005 though. To simulate similar values as observed on 20 December over Cotonou, we suggest that an exceptional release of VOCs and $\mathrm{NO}_{\mathrm{x}}$ took place near Lagos. A pipeline explosion due to a leak of hydrocarbons would emit large quantities of reactive hydrocarbons and $\mathrm{NO}_{\mathrm{x}}$. Such a pipeline explosion actually occured on the morning of the 20 December 2005 in the vicinity of Port Harcourt in the Niger Delta river. The fire was not completely extinguished until 4 days later. The loss of gas has been estimated to be $7 \%$ of the daily production (Agence France Presse, 2006). Thus, it may be not surprising to have such accidents in the city of Lagos.

Therefore, we conduct a third set of runs called Additional petrochemical Accident which simulates the passing of the air mass already charged in biomass burning over a hypothetical release of VOCs and $\mathrm{NO}_{\mathrm{x}}$ from a petrochemical source. As with the second set of runs, it begins at 06:00 LT (local time) and lasts for 3 days ( $72 \mathrm{~h}$ ). This time we feed the biomass burning plume with $320 \mathrm{ppb}$ of extra reactive VOCs and $55 \mathrm{ppb}$ of $\mathrm{NO}_{\mathrm{x}}$ to represent emissions of petrochemical compounds. Those values are based on different records from literature, which are detailed in Table 2 and are in the upper range of these values. As far as we know, very few measurements of ozone (and precursors) concentrations have been made during incidents or explosions in petrochemical industries. As an example, reports on high VOCs emissions are available in Canada (in the region of Montreal), mentioning a probable industrial incident on 20 October 2003, with total VOCs concentration close to $1000 \mu \mathrm{g} \mathrm{m}^{-3}$ (http://www.ec.gc.ca/ cleanair-airpur/caol/trackingbenzene/p4_f.cfm\#journees, in french), and among them, benzene concentrations of $34 \mathrm{ppb}$ $\left(120 \mathrm{\mu g} \mathrm{m}^{-3}\right)$. Figure $9 \mathrm{c}$ shows the result of this last set of runs. Ozone concentration increases by $170 \mathrm{ppb}$ in $\sim 5 \mathrm{~h}$ (around noon local time) and reach a maximum of about $250 \mathrm{ppb}$. This gives an estimate of the ozone production rate of $34 \mathrm{ppbh}^{-1}$, which is in the range of the ozone production rates calculated in the studies referenced in Table 2. The ozone concentration remains higher than $150 \mathrm{ppb}$ and $130 \mathrm{ppb}$ for more than 3 days for the 10 days dilution run and the 5 days dilution run respectively. The sounding recorded on 22 December 2005 shows that ozone concentrations were lower than those on 20 December 2005 down to $65-80 \mathrm{ppb}$ but still higher than the ones recorded on the 16 December 2005 (40-70 ppb) as seen in Fig. 3. The sounding on the 22 December 2005 has probably sampled a different polluted plume from the one of the 20 December. This seems to be confirmed by the box model run, which simulates the aging and the dilution of the polluted mass sampled the 20 December.

The set of runs Additional Petrochemical Accident presented in Fig. 9c uses arbitrary values. To better assess the amounts of VOCs and $\mathrm{NO}_{\mathrm{x}}$ that are necessary to produce ozone concentrations as high as observed on 20 December 2005 over Cotonou, we actually performed 49 sensitivity studies. In these test runs the $\mathrm{NO}_{\mathrm{x}}$ concentrations vary from 6 to $78 \mathrm{ppb}$ and the VOCs amount from 55 to $555 \mathrm{ppb}$. Figure 10 shows the isopleths of the maximum ozone concentrations reached before the end of the simulation as a function of the initial $\mathrm{NO}_{\mathrm{x}}$ and VOCs amounts. The results of the first two simulations are recalled on this contour plot as the blue points on the left hand side. Figure 10 shows that a combination of $250-600 \mathrm{ppb}$ of VOCs and 35-80 ppb of $\mathrm{NO}_{\mathrm{x}}$ are necessary to produce more than $250 \mathrm{ppb}$ of ozone. These ranges of concentrations do not correspond to biomass burning nor regular anthropogenic pollution but rather to emissions from a petrochemical accident.

\section{Conclusions}

As part of the AMMA program, ozone soundings over Cotonou were launched between December 2004 and January 2007. In December 2005, particularly high ozone concentrations have been recorded throughout the troposphere (Thouret et al., 2009). This paper focuses on the ozone vertical profile measured on 20 December 2005. This day is characterized by an exceptional ozone enhanced layer peaking at around $1 \mathrm{~km}$ altitude. This layer is about $1.5 \mathrm{~km}$ thick and ozone concentrations are up to almost $300 \mathrm{ppb}$ within it. 
Such high concentrations were previously reported in China (Wang et al., 2006), in Mexico City (Molina et al., 2007) and close to petrochemical industries near Houston in USA (Kleinman et al., 2002, 2005). However such event has never been reported over Africa and we reported here the first one of the region.

We have shown that the $294 \mathrm{ppb}$ of ozone measured on 20 December 2005 are far higher than the typical ozone concentrations recorded over West Africa provided by the MOZAIC and AMMA programs, which are lower than $120 \mathrm{ppb}$. The wind pattern indicates that Cotonou is under the influence of the Harmattan flow at this time of the year and that its atmosphere is impacted by biomass burning pollution. We used Flexpart backward trajectories and a photochemical zero-dimensional model including dilution effect to built a scenario that explains how such high ozone concentrations could be produced in the vicinity of Cotonou. When the biomass burning emissions of VOCs and $\mathrm{NO}_{\mathrm{x}}$ are included in the model as initilization, the model simulates only up to $110 \mathrm{ppb}$ of ozone, which is in agreement with the typical ozone concentrations within biomass burning plumes. Adding urban emissions from the city of Lagos to the plume impacted by biomass burning does increase the ozone level but it remains below $120 \mathrm{ppb}$. To simulate ozone concentrations close to $300 \mathrm{ppb}$, we needed to assume that there was a release of large quantities of VOCs and $\mathrm{NO}_{\mathrm{x}}$ as in a petrochemical accident. This kind of accident is known to happen frequently in Nigeria and in the vicinity of Lagos (see appendix below for further details). Including these high emissions of VOCs and $\mathrm{NO}_{\mathrm{x}}$ in the box model allowed the model to produce up to $170 \mathrm{ppb}$ of ozone in a few hours and the ozone concentrations to reach about $250 \mathrm{ppb}$. Sensitivity tests showed that only $250-600 \mathrm{ppb}$ of VOCs combined with $35-80 \mathrm{ppb}$ of $\mathrm{NO}_{\mathrm{x}}$ allow the ozone concentrations to be higher than $250 \mathrm{ppb}$.

Unfortunately, we did not find any proof of such petrochemical accident in the area of Lagos during this period (16-19 December 2005) using satellite data or daily news. However, this scenario is the most likely one. Such event has been probably very limited in time and space but it should be remembered in future studies regarding air quality issue in this region as a non negligeable source of ozone and its impact.

\section{Appendix A}

\section{Analysis of newspaper articles}

The Nigerian National Petroleum Corporation (NNPC) reports a total of 2258 breaks of pipelines for the year 2005, which is higher than for the years 2006 and 2007. Most of them (2237) are due to vandalism (NNCP, 2005). The region of Port Harcourt (Niger delta) is the most frequently attacked one. However the Lagos urban area has experienced
194 vandalism acts, and 15 accidental breaks during the year 2005. Nigeria has $5000 \mathrm{~km}$ of pipelines, which are regularly sabotaged has declared Funsho Kupolokun, president of the NNPC in front of the federal Parliament on 23 January 2007 (This Day, national daily newspaper, 24 January 2007.) Such pipeline breaks are frequent and sometimes associated to intense fires. Besides the loss of oil, the consequences are dramatic for the vegetation, and one can often deplore the death of animals and human beings (Otitoloju et al., 2007). This Day has reported two murderous accidents for the 18 and 20 December 2005. Indeed, on the 20 December 2005, This Day reports an explosion of a pipeline in Port Harcourt killing 8 persons. These examples show the frequency of such accidents. We did not find any proof of something on 19 December 2005 around Lagos but it does not mean that nothing happened. It may probably only means that nobody has been killed by such an explosion on this day, hopefully.

Acknowledgements. Based on a French initiative, AMMA was built by an international scientific group and is currently funded by a large number of agencies, especially from France, the UK, the USA, and Africa. It has been the beneficiary of a major financial contribution from the European Communitys Sixth Framework Research Programme. Detailed information on scientific coordination and funding is available on the AMMA International Web site at www.amma-international.org. Besides, authors warmly thank all the people from IRD based in Cotonou for their help before, during and after this sounding operation, as well as Mrs F. Didé, A. Solete and D. Agbangla from SMN/ASECNA. Finally, collaborations with Mrs A. Akpo, E. Houngninou and B. Kounouhewa from the University of Abomey-Calavi have been really appreciated.

Edited by: F. Dentener

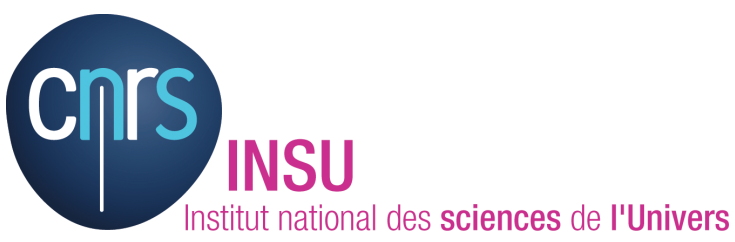

The publication of this article is financed by CNRS-INSU.

\section{References}

Aghedo, A. M., Schultz, M. G., and Rast, S.: The influence of African air pollution on regional and global tropospheric ozone, Atmos. Chem. Phys., 7, 1193-1212, 2007, http://www.atmos-chem-phys.net/7/1193/2007/.

Andreae, M. and Merlet, P.: Emission of trace gases and aerosols from biomass burning, Global Biogeochem. Cy., 15, 955-966, 2001.

Arnold, S. R., et al.: Statistical inference of $\mathrm{OH}$ concentrations and air mass dilution rates from successive observations of nonmethane hydrocarbons in single air masses, J. Geophys. Res., 112, D10S40, doi:10.1029/2006JD007594, 2007.

Baumbach, G., Vogt, U., Hein, K., Oluwole, A., Ogunsola, O., Olaniyi, H., and Akeredolu, F.: Air pollution in 
a large tropical city with a high traffic density - results of measurements in Lagos, Nigeria, Sci. Total Environ., 169, $25-$ 31, doi:10.1016/0048-9697(95)04629-F, 1995.

Berkowitz, C. M., Jobson, T., Jiang, G., Spicer, C. W., and Doskey, P. V.: Chemical and meteorological characteristics associated with rapid increases of $\mathrm{O}_{3}$ in Houston, Texas, J. Geophys. Res., 109, D10307, doi:10.1029/2003JD004141, 2004.

Butler, T. M., Taraborrelli, D., Brühl, C., Fischer, H., Harder, H., Martinez, M., Williams, J., Lawrence, M. G., and Lelieveld, J.: Improved simulation of isoprene oxidation chemistry with the ECHAM5/MESSy chemistry-climate model: lessons from the GABRIEL airborne field campaign, Atmos. Chem. Phys., 8, 4529-4546, 2008, http://www.atmos-chem-phys.net/8/4529/2008/.

Carmichael, G. R., Ferm, M., Thongboonchoo, N., Woo, J. H., Chan, L. Y., Murano, K., Viet, P. H., Mossberg, C., Bala, R., Boonjawat, J., Upatum, P., Mohan, M., Adhikary, P., Shrestha, A. B., Pienaar, J. J., Brunke, E. B., Chen, T., Jie, T., Guoan, D., Peng, L. C., Dhiharto, S., Harjanto, H., Jose, A. M., Kimani, W., Kirouane, A., Lacaux, J. P., Richard, S., Barturen, O., Carrasco Cerda, J., Athayde, A., Tavares, T., Cotrina, J. S., and Bilici, E.: Measurements of sulfur dioxide, ozone and ammonia concentrations in Asia, Africa, and South America using passive samplers, Atmos. Env., 37, 1293-1308, 2003.

Cros, B., Fontan, J., Minga, A., Helas, G., Nganga, D., Delmas, R., Chapuis, A., Benech, B., Druilhet, A., and Andrea, M.: Vertical profiles of ozone between 0 and $400 \mathrm{~m}$ in and above an African Equatorial forest, J. Geophys. Res., 97, 12877-12887, 1992.

Cros, B., Delon, C., Affre, C., Marion, T., Druilhet, A., Perros, P., and Lopez, A.: Sources and sinks of ozone in savanna forest areas during EXPRESSO: Airborne turbulent flux measurements, J. Geophys. Res., 105, 29347-29358, 2000.

Delmas, R. A., Druilhet, A., Cros, B., et al.: Experiment for Regional Sources and Sinks of Oxidants (EXPRESSO): An overview, J. Geophys. Res., 104, 30609-30624, 1999.

de Foy, B., Caetano, E., Magaña, V., Zitácuaro, A., Cárdenas, B., Retama, A., Ramos, R., Molina, L. T., and Molina, M. J.: Mexico City basin wind circulation during the MCMA-2003 field campaign, Atmos. Chem. Phys., 5, 2267-2288, 2005, http://www.atmos-chem-phys.net/5/2267/2005/.

Fanou, L., Mobio, T., Creppy, E., Fayomi, B., Fustoni, S., Moller, P., Kyrtopoulos, S., Georgiades, P., Loft, S., Sanni, A., Skov, H., Ovrebo, S., and Autrup, H.: Survey of air pollution in Cotonou, Benin - air monitoring and biomarkers, Sci. Total Environ., 358, 85-96, doi:10.1016/j.scitotenv.2005.03.025, 2006.

Guangfeng, J. and Fast, J. D.: Modeling the effects of VOC and $\mathrm{NO}_{\mathrm{x}}$ emission sources on ozone formation in Houston during the TexAQS 2000 field campaign, Atmos. Environ., 38, 5071-5085, 2004.

Guenther, A., Karl, T., Harley, P., Wiedinmyer, C., Palmer, P. I., and Geron, C.: Estimates of global terrestrial isoprene emissions using MEGAN (Model of Emissions of Gases and Aerosols from Nature), Atmos. Chem. Phys., 6, 3181-3210, 2006, http://www.atmos-chem-phys.net/6/3181/2006/.

Guenther, A., Hewitt, C. N., Erickson, D., Fall, R., Geron, C., Graedel, T., Harley, P., Klinger, L., Lerdau, M., McKay, W. A., Pierce, T., Scholes, B., Steinbrecher, R., Tallamraju, R., Taylor, J., and Zimmerman, P.: A global model of natural volatile organic compound emissions, J. Geophys. Res., 100, 8873-8892,
1995.

Haywood, J. M., Pelon, J., Formenti, P., et al.: Overview of the Dust and Biomass-burning Experiment and African Monsoon Multidisciplinary Analysis Observing Period-0, J. Geophys. Res., 113, D00C17, doi:10.1029/2008JD010077, 2008.

Höller, H., Betz, H.-D., Schmidt, K., Calheiros, R. V., May, P., Houngninou, E., and Scialom, G.: Lightning characteristics observed by a VLF/LF lightning detection network (LINET) in Brazil, Australia, Africa and Germany, Atmos. Chem. Phys., 9, 7795-7824, 2009, http://www.atmos-chem-phys.net/9/7795/2009/.

Hopkins, J. R., Evans, M. J., Lee, J. D., Lewis, A. C., H Marsham, J., McQuaid, J. B., Parker, D. J., Stewart, D. J., Reeves, C. E., and Purvis, R. M.: Direct estimates of emissions from the megacity of Lagos, Atmos. Chem. Phys., 9, 8471-8477, 2009, http://www.atmos-chem-phys.net/9/8471/2009/.

Hung-Lung, C., Jiun-Horng, T., Shih-Yu, C., Kuo-Hsiung, L., and Sen-Yi, M.: VOC concentration profiles in an ozone nonattainment area: A case study in an urban and industrial complex metroplex in southern Taiwan, Atmos. Environ., 41(9), 18481860, 2007.

Jacob, D. J., Heikes, E. G., Fan, S.-M., Logan, J. A., et al.: Origin of ozone and $\mathrm{NO}_{\mathrm{x}}$ in the tropical troposphere: A photochemical analysis of aircraft observations over the South Atlantic basin, J. Geophys. Res., 101(D19), 23889-23907, 1996.

Jaeglé, L., Martin, R., Chance, K., Steinberger, L., Kurosu, T., Jacob, D., Modi, A., Yoboué, V., Sigha-Nkamdjou, L., and Galy-Lacaux, C.: Satellite mapping of rain-induced nitric oxide emissions from soils, J. Geophys. Res., 109, D21310, doi:10.1029/2004JD004787, 2004.

Jaeglé, L., Steinberger, L., Martin, R., and Chance, K.: Global partitionning of $\mathrm{NO}_{\mathrm{x}}$ sources using satellite observations: relative roles of fossil fuel combustion, biomass burning and soils emissions, Faraday Discuss., 130, 1-17, 2005.

Janicot, S., Thorncroft, C. D., Ali, A., Asencio, N., Berry, G., Bock, O., Bourles, B., Caniaux, G., Chauvin, F., Deme, A., Kergoat, L., Lafore, J.-P., Lavaysse, C., Lebel, T., Marticorena, B., Mounier, F., Nedelec, P., Redelsperger, J.-L., Ravegnani, F., Reeves, C. E., Roca, R., de Rosnay, P., Schlager, H., Sultan, B., Tomasini, M., Ulanovsky, A., and ACMAD forecasters team: Large-scale overview of the summer monsoon over West Africa during the AMMA field experiment in 2006, Ann. Geophys., 26, 25692595, 2008, http://www.ann-geophys.net/26/2569/2008/.

Jonquière, I., Marenco, A., Maalej, A., and Rohrer, F.: Study of ozone formation and transatlantic transport from biomass burning emissions over West Africa during the airborne Tropospheric Ozone Campaigns TROPOZ I and TROPOZ II, J. Geophys. Res., 103, 19059-19073, 1998.

Kleinman, L. I., Daum, P. H., Imre, D., Lee, Y.-N., Nunnermacker, L. J., Springston, S. R., Weinstein-Lloyd, J., and Rudolph, J.: Ozone production rate and hydrocarbon reactivity in 5 urban areas: A cause of high ozone concentration in Houston, Geophys. Res. Lett., 29(10), 1467, doi:10.1029/2001GL014569, 2002.

Kleinman, L. I., Daum, P. H., Lee, Y.-N., Nunnermacker, L. J., Springston, S. R., Weinstein-Lloyd, J., and Rudolph, J.: A comparative study of ozone production in five US metropolitan areas, J. Geophys. Res., 110, D02301, doi:10.1029/2004JD005096, 
2005.

Lawrence, M. G., Butler, T. M., Steinkamp, J., Gurjar, B. R., and Lelieveld, J.: Regional pollution potentials of megacities and other major population centers, Atmos. Chem. Phys., 7, 39693987, 2007, http://www.atmos-chem-phys.net/7/3969/2007/.

Linden, J., Thorsson, S., and Eliasson, I.: Carbon Monoxide in Ouagadougou, Burkina Faso - A comparison between urban background, roadside and in-traffic measurements, Water Air Soil Poll., 188, 345-353, doi:10.1007/s11270-007-9538-2, 2008.

Madronich, S. and Calvert, J. G.: The NCAR Master Mechanism of the gas phase chemistry, NCAR technical Note, TN-333+SRT, Boulder Colorado, 1990.

Madronich, S. and Flocke, S.: The role of solar radiation in atmospheric chemistry, in: The Handbook of Environmental Photochemistry, Vol. 2: Reactions and Processes, Part L, edited by: Hutzinger, O., Springer-Verlag, New York, 1-26 pp., 1998.

Madronich, S.: Chemical evolution of gaseous air pollutants downwind of tropical megacities: Mexico City case study, Atmos. Environ., 40, 6012-6018, 2006.

Marenco, A., Thouret, V., Nédélec, P., Smit, H., Helten, M., Kley, D., Karcher, F., Simon, P., Law, K., Pyle, J., Poschmann, G., Von Wrede, R., Hume, C., and Cook, T.: Measurement of ozone and water vapor by airbus in-service aircraft: The MOZAIC airborne program, An Overview, J. Geophys. Res., 103, 25631-25642, 1998.

Molina, L. T., Kolb, C. E., de Foy, B., Lamb, B. K., Brune, W. H., Jimenez, J. L., Ramos-Villegas, R., Sarmiento, J., ParamoFigueroa, V. H., Cardenas, B., Gutierrez-Avedoy, V., and Molina, M. J.: Air quality in North America's most populous city overview of the MCMA-2003 campaign, Atmos. Chem. Phys., 7, 2447-2473, 2007,

http://www.atmos-chem-phys.net/7/2447/2007/.

Moxim, W. J. and Levy, H.: A model analysis of the tropical South Atlantic Ocean tropospheric ozone maximum: The interaction of transport and chemistry, J. Geophys. Res., 105, 17393-17415, 2000.

NNCP: Nigerian national petroleum corporation, 2005 annua statistical bulletin, www.nnpcgroup.com, last access: December 2009, 2005.

Otitoloju, A. A., Are, T., and Junaid, K. A.: Recovery assessment of a refined-oil impacted and fire ravaged mangrove ecosystem, Environ. Monit. Assess, 127, 353-362, doi:10.1007/s10661-0069285-7, 2007.

Poppe, D., Koppmann, R., and Rudolph, J.: Ozone formation in biomass burning plume: Influence of atmospheric dilution, Geophys. Res. Lett., 25, 3823-3826, 1998.

Ryerson, T. B., Trainer, M., Angevine, W. M., Brock, C. A., et al.: Effect of petrochemical industrial emissions of reactive alkenes and $\mathrm{NO}_{\mathrm{x}}$ on tropospheric ozone formation in Houston, Texas, J. Geophys. Res., 108(D8), 4249, doi:10.1029/2002JD003070, 2003.

Sauvage, B., Thouret, V., Cammas, J.-P., Gheusi, F., Athier, G., and Nédélec, P.: Tropospheric ozone over Equatorial Africa: regional aspects from the MOZAIC data, Atmos. Chem. Phys., 5, 311335,2005 ,

http://www.atmos-chem-phys.net/5/311/2005/.

Sauvage, B., Martin, R. V., van Donkelaar, A., Liu, X., Chance, K., Jaeglé, L., Palmer, P. I., Wu, S., and Fu, T.-M.: Remote sensed and in situ constraints on processes affecting tropical tropospheric ozone, Atmos. Chem. Phys., 7, 815-838, 2007, http://www.atmos-chem-phys.net/7/815/2007/.

Serça, D., Delmas, R., Le Roux, X., Parsons, D. A. B., Scholes, M. C., Abbadie, L., Lensi, R., Ronce, O., and Labroue, L.: Comparison of nitrogen monoxide emissions from several African tropical ecosystems and influence of season and fire, Global Biogeochem. Cy., 12, 637-651, 1998.

Spirig, C., Neftel, A., Kleinman, L. I., and Hjorth, J.: $\mathrm{NO}_{\mathrm{x}}$ versus VOC limitation of $\mathrm{O}_{3}$ production in the Po valley: Local and integrated view based on observations, J. Geophys. Res., 107(D22), 8191, doi:10.1029/2001JD000561, 2002.

Stewart, D. J., Taylor, C. M., Reeves, C. E., and McQuaid, J. B.: Biogenic nitrogen oxide emissions from soils: impact on $\mathrm{NO}_{\mathrm{x}}$ and ozone over west Africa during AMMA (African Monsoon Multidisciplinary Analysis): observational study, Atmos. Chem. Phys., 8, 2285-2297, 2008, http://www.atmos-chem-phys.net/8/2285/2008/.

Stohl, A., Forster, C., Frank, A., Seibert, P., and Wotawa, G.: Technical note: The Lagrangian particle dispersion model FLEXPART version 6.2, Atmos. Chem. Phys., 5, 2461-2474, 2005, http://www.atmos-chem-phys.net/5/2461/2005/.

Swap, R. J., Suttles, J. T., King, M. D., Platnick, S., Privette, J. L., and Scholes, R. J.: Africa burning: A thematic analysis of the Southern African Regional Science Initiative (SAFARI 2000), J. Geophys. Res., 108(D13), 8465, doi:10.1029/2003JD003747, 2003.

Thouret, V., Saunois, M., Minga, A., Mariscal, A., Sauvage, B., Solete, A., Agbangla, D., Nédélec, P., Mari, C., Reeves, C. E., and Schlager, H.: An overview of two years of ozone radio soundings over Cotonou as part of AMMA, Atmos. Chem. Phys., 9, 6157-6174, 2009, http://www.atmos-chem-phys.net/9/6157/2009/.

Thompson, A. M., Diab, R. D., Bodeker, G. E., Zunckel, M., Coetzee, G. J. R., Archer, C. B., McNamara, D. P., Pickering, K. E., Combrink, J., Fishman, J., and Nganga, D.: Ozone over southern Africa during SAFARI-92 TRACE A, J. Geophys. Res., 101(D19), 23793-23807, 1996

Tie, X., Madronich, S., Li, G., Ying, Z., Zhang, R., Garcia, A. R., Lee-Taylor, J., and Liu, Y.: Characterizations of chemical oxidants in Mexico City: A regional chemical dynamical model (WRF-Chem) study, Atmos. Environ., 41, 1989-2008, 2007.

van der Werf, G. R., Randerson, J. T., Giglio, L., Collatz, G. J., Kasibhatla, P. S., and Arellano Jr., A. F.: Interannual variability in global biomass burning emissions from 1997 to 2004, Atmos. Chem. Phys., 6, 3423-3441, 2006, http://www.atmos-chem-phys.net/6/3423/2006/.

Wang, T., Ding, A., Gao, J., and Wu, W. S.: Strong ozone production in urban plumes from Beijing, China, Geophys. Res. Lett., 33, L21806, doi:10.1029/2006GL027689, 2006.

West, J. J., Zavala, M. A., Molina, L. T., Molina, M. J.,San Martini, F., McRae, G. J., Sosa-Iglesias, G., and Arriaga-Colina, J. L.: Modeling ozone photochemistry and evaluation of hydrocarbon emissions in the Mexico City metropolitan area, J. Geophy. Res., 109, D19312, doi:10.1029/2004jd004614, 2004.

Zhang, R., Lei, W., Tie, X., and Hess, P.: Industrial emissions cause extreme urban ozone diurnal variability, P. Natl. Acad. Sci. USA, 101(17), 6346-6350, 2004. 